\title{
Lecturer Academic Performance: A Descriptive Review
}

\author{
Bambang Yulianto \\ Universitas Negeri Surabaya, Indonesia \\ Anas Ahmadi* \\ Universitas Negeri Surabaya, Indonesia \\ I Gusti Lanang Putra Eka Prismana \\ Universitas Negeri Surabaya, Indonesia
}

\begin{abstract}
One of the challenges of tertiary institutions at present is the progressiveness of lecturers' academic performance. Higher education institutions whose progress in academic performance will certainly show the quality level of the tertiary institution. This research presents the academic performance of lecturers in tertiary institutions. The aim of this study is to describe academic lecturers which based academic publish in google scholar. The research approach used is descriptive qualitative method because this study prioritizes verbal exposure. The data used is documentary based which is obtained from the google scholar database. Data analysis techniques use stages in a qualitative approach: identification, classification, and data analysis. The results showed that the highest number of publications was Post Graduate (PPs), while the lowest number of publications was (Sport Science Faculty) FIO. Based on these results, it proved that Post Graduate (PPs) dominated in terms of the number of publications because Post Graduate (PPs) is dominated by lecturers with higher academic levels.
\end{abstract}

Keywords: academic performance, publications, universities

DOI: $10.7176 / \mathrm{JEP} / 10-33-02$

Publication date: November $30^{\text {th }} 2019$

\section{Preliminary}

The challenges of Indonesian universities today are government policy, campus autonomy, easy access, gender equality, quality-quantity, and internationalization (Logli, 2016; Soedjatminah, 2009; Knight, 2001). One of the things related to the quality of higher education is the progressiveness of the academic performance of lecturers. The progressiveness of lecturers' academic performance is a demand from various universities. The higher the academic performance of a tertiary institution, the better the academic performance of the tertiary institution. Conversely, the low progression of academic performance of lecturers will make higher academic performance of higher education institutions. The high and low academic performance will have an impact on (1) the number of prospective students who wish to apply to the tertiary institution; (2) number of graduate users; and (3) the image of tertiary institutions in the eyes of the community. The higher the progressiveness of the academic performance of a tertiary institution, the better the number of applicants, the number of graduates, and the image of the tertiary institution in the eyes of the public. In this context, the academic performance of lecturers is more focused on academic publications (in the form of books, journal articles, seminar articles, and those relevant to the academic field).

Several studies relating to lecturer performance focused on publications have been conducted by Elfindri et al (2015), Hemmings and Hill (2009), Hemmings \& Kay (2007). From the researchers, it appears that what is more highlighted in relation to the academic performance of lecturers is the publication of journal articles and book publications. Both journal articles and books are publications that are a must for lecturers as professionals. Logically, the more scientific publications a lecturer has, the higher the competence of the lecturer. However, it cannot be denied that in certain contexts this does not apply. In the context of the world of publication, there are the following character writers. First, writers who produce a lot of quality publications and works. Second, there are writers who produce a lot of work, but the quality of their writing is low. Third, there are writers who write with ordinary intensity, but quality. Fourth, there are writers who rarely write, but the quality of their writing is high, and lastly there are those who rarely write and their writing quality is also low.

Related to this in this study explored the academic performance of lecturers in Indonesia in this case focused on Surabaya State University. This study uses a qualitative-descriptive approach because researchers use verbal data in data exposure and further strengthen cognition (Berg, 2012, Cresswel, 2009, Ely et al, 1991). It's just that, in research it is used graphs to support data exposure. Data collection techniques were carried out by means of documentative studies related to the performance of Surabaya State University lecturers. The documentary study was used to encompass the publications of lecturers at Surabaya State University in the 20172019 range. Related to that, lecturers in this context lecturer performance is reviewed from each faculty, namely the Faculty of Language and Arts (FBS), Faculty of Economics (FE), Faculty of Sport Sciences (FIO), Faculty of 
Education (FIP), Faculty of Social Sciences (Faculty of Science Social), Faculty of Mathematics and Natural Sciences (FMIPA), Postgraduate (PPs) (in this context PPs are equated with faculties to make it easy to mention them, and the Faculty of Engineering (FT). Data analysis techniques use stages in a qualitative approach which includes identification of related data with the performance of Surabaya State University lecturers, Surabaya State University lecturer performance classification, and analysis of Surabaya State University lecturer performance data.

\section{Discussion Results Discussion}

Surabaya State University is a state university located in Surabaya, East Java, Indonesia. Surabaya State University if traced historically was born on December 19, 1964 and at this time was named IKIP Surabaya. Surabaya State University is a university that was originally based at Malang State University. Based on Presidential Decree No. 93 of 1999, IKIP Surabaya underwent a change and became Surabaya State University. The academic performance of lecturers related to publications indexed by Google Scholar in 2017 is as follows. FBS has 129 publications; FE has 176 publications; FIO 133 works; FIP has 145 publications; FIS has 261 publications; MIPA 318; PPs have 467 publications; FT has a number of publications of 315. If visualized, the academic performance of the lecturer can be seen in the following visualization.

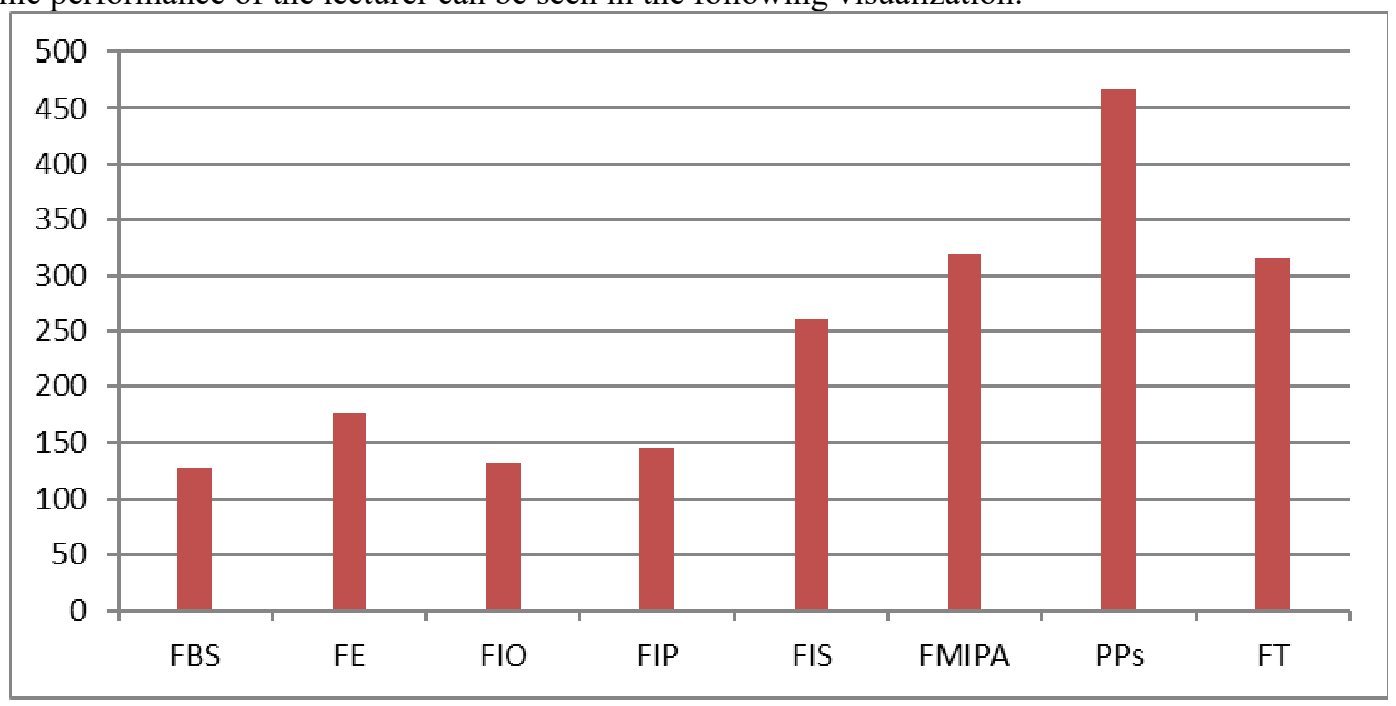

Table 1 Data based on Google Scholar per Faculty 2017

Based on table 1 it appears that PPS ranks highest in publications. The second sequence of publications is FMIPA. The third place is occupied by FT. The fourth sequence is occupied by the FIS. The fifth rank is occupied by FE, followed by FIP in the sixth position. Seventh is occupied by FIO and finally FBS.

The academic performance of lecturers related to publications indexed by Google Scholar in 2018 is as follows. FBS has 109 publications; FE has 112 publications; FIO 30 works; FIP has 30 publications; FIS has 103 publications; Mathematics and Natural Sciences 335; PPs have a total of 558 publications; FT has a number of publications of 158. If visualized, the academic performance of the lecturer can be seen in the following visualization. 


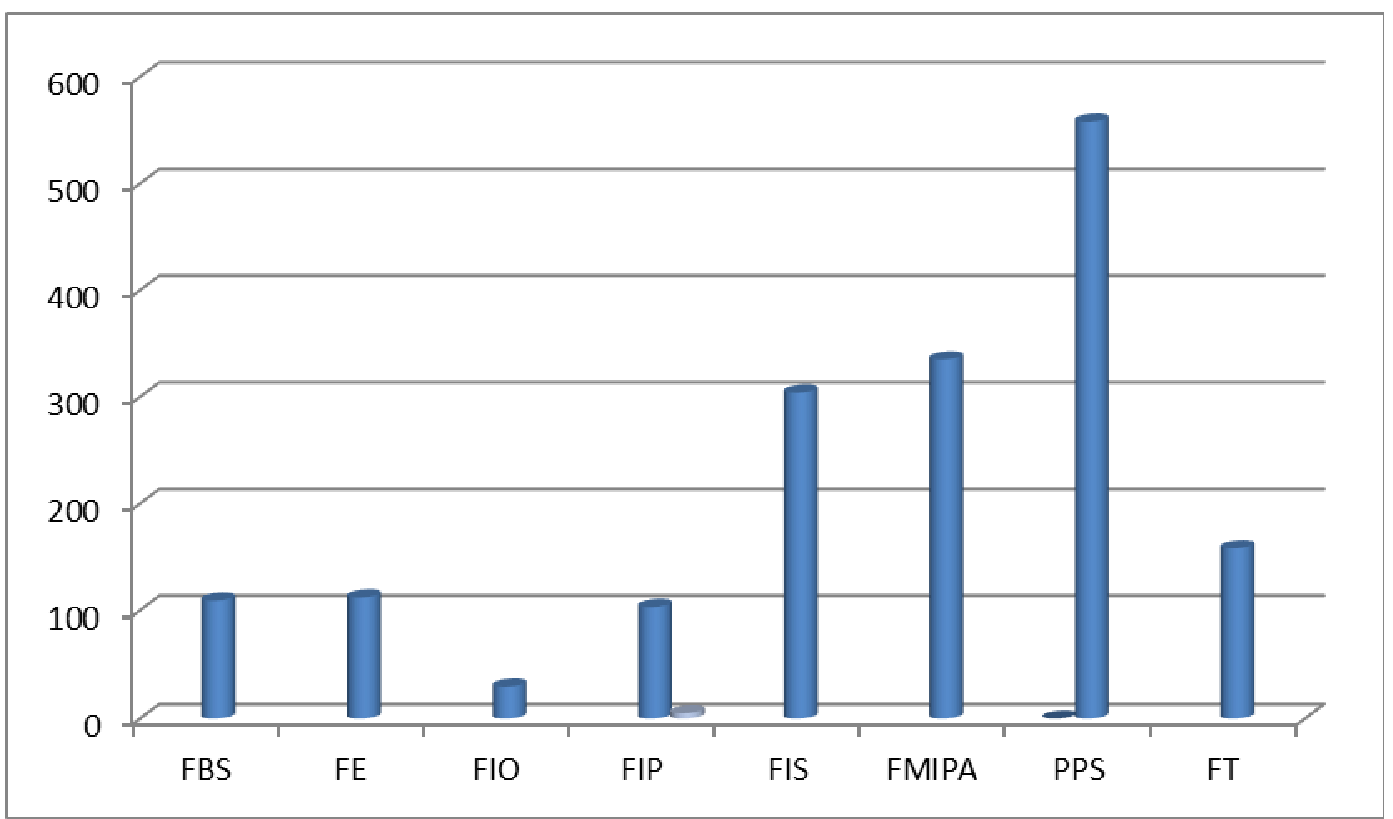

Table 2 Data based on Google Scholar per Faculty 2018

Based on table 2 it appears that PPS ranks highest in publications. The second sequence of publications is FMIPA. The third place is occupied by the FIS. The fourth sequence is occupied by FT. The fifth was occupied by FE, followed by FBS in sixth position. Seventh is occupied by FIP and finally FIO.

The academic performance of lecturers relating to publications indexed by Google Scholar in 2019 is as follows. FBS has 41 publications; FE has 53 publications; FIO 9 works; FIP has 35 publications; FIS has 127 publications; MIPA 139; PPs have 174 publications; FT has a number of publications of 1 . If visualized, the academic performance of the lecturer can be seen in the following visualization.

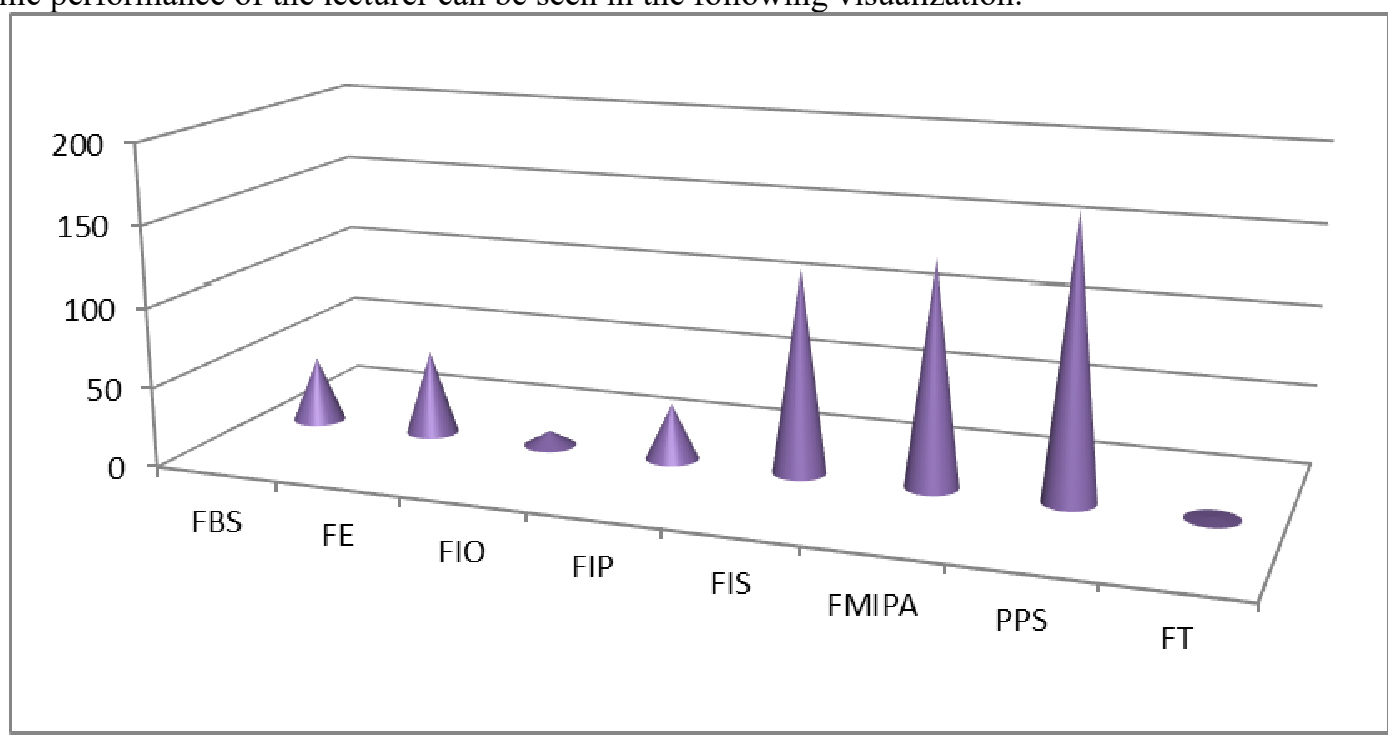

Table 3 Data based on Google Scholar per Faculty 2019

Based on table 3 it appears that PPS ranks highest in publications. The second sequence of publications is FMIPA. The third place is occupied by the FIS. The fourth sequence is occupied by FT. The fifth was occupied by FE, followed by FBS in sixth position. Seventh is occupied by FIP and finally FIO.

Associated with academic performance data of lecturers indexed by Sinta (Science and Technology Index). Sinta is a database of academic portals in Indonesia. in it contains data about lecturers, publication data, book data, journal data, citation data, IPR data, and those related to the academic context. The data in Sinta is open access data that can be seen by everyone (Ahmadi, 2019). Thus, the general public or academic community can get information easily from Sprott. However, in this study researchers did not use Sinta as a database because the database derived from Sinta was taken from Google Scholar.

\section{Conclusions}

From google scholar data, it can be seen that PPS has the highest number of academic publications among other 
faculties (note: in this case, PPS is equivalent to faculty). FMIPA ranks second in ranking the number of academic publications. The third place is occupied by the FIS. As for the order with the least amount of publication, FIO. Even from 2017 to 2019 FIO has decreased which can be quite drastic. In addition to all of these things, data from Google Scholar shows that a lot of data is obtained that is significant enough to find out how much productivity each faculty has.

\section{References}

Ahmadi, A. (2019) The Use of Sinta (Science and Technology Index) Database to Map the Development Of Literature Study In Indonesia. International Journal of Mechanical Engineering and Technology (IJMET), $10(2): 918-923$

Berg, B. L. (2012). Qualitative Research Methods for the Social Science (8th Ed.). Long Beach: Allyn and Bacon.

Creswell, J. W. (2009). Research Design: Qualitative, Quantitative and Mixed Method Approaches (3rd Ed.). Los Angeles: SAGE Publications

Ely, M., Anzul, M., Friedman, T., Garner, D., \& Steinmetz, A. (1991). Doing Qualitative Research: Circles within Circles. London: Falmer Press.

Hemmings, B. and Hill, D. 2009. The development of lecturer research expertise: Towards a unifying model. Issues in Educational Research, 19(1):14-24.

Hemmings, B. \& Kay, R. (2007). I'm sure I can write! Writing confidence and other factorswhich influence academic output. Paper presented at the European College Teaching and Learning Conference, Ljubljana, Slovenia.

Elfindri, E. et al. (2015). Lecturer Performances In Indonesia Higher Education System. Ijaedu- International EJournal of Advances in Education, 1 (1):26-36.

Knight, J. (2001). Monitoring the quality and progress of internationalization. Journal of Studies in International Education, 5 (3), 228-243

Logli, C. (2016). "Higher Education in Indonesia: Contemporary Challenges in Governance, Access, and Quality.” In D. Neubauer, J. Hawkins, M. Lee, \& C. Collins (Eds.), Handbook of Asian Higher Education. New York City, NY: Palgrave Macmillan.

Soejatminah, S. (2009). "Internationalisation of Indonesian Higher Education: A Study from the Periphery." Asian Social Science, No. 5 (9):70-78. 